\title{
Implikasi Yuridis Legalitas Kewenangan (Rechtmatigheid) Majelis Kehormatan Dalam Pembinaan Notaris Sebagai Pejabat Publik
}

\author{
Oleh \\ I Wayan Parsa \\ Kadek Sarna \\ Nengah Suharta \\ Program Studi Magister (S2) Kenotariatan Universitas Udayana
}

\begin{abstract}
The enactment of Amendment Act No.30 year of 2004 intoAct No.2 of 2014, gave rise to a new agency called the Notary Honorary Assembly who has the tasks of guidancewhereas regulated in Article 66A Paragraph (1). On the other hand pursuant to Article 1 paragraph (6) of the mentioned Notary Supervisory assembly has the authority and obligation to implement the guidance and supervision of Notary. Juridical implications that happened was a conflict between the provisions of norms in the provisions of Article 1 paragraph(6), Article 66A and Article 67 Act No. 2 of 2014 on the Amendment of Act No.30 of 2004. Using The normative legal research methods legislation approach (Statue Approach) and Approach Analysis of Legal Concepts (Analytical Conceptual Approach), the author will analyze the juridical scope of authority of the existence of the Notary HonoraryAssembly and Notary SupervisioryAssembly and legal authority of the function of the Honorary Council of Notary within the institution notary so there is no conflict of authority between the two institutions the notary.
\end{abstract}

Keywords: Juridical Implications, legality, authority, Notary Honorary Assembly.

\section{Abstrak}

Diundangkannya UU Perubahan Atas Undang-Undang No.30 Tahun 2004 yaitu Undang Undang No.2 Tahun 2014, memunculkan lembaga baru yang disebut Majelis Kehormatan Notaris yang mempunyai tugas melaksanakan pembinaan sebagaiman diatur dalam Pasal 66A ayat (1). Disisi lain berdasarkan Pasal 1 angka (6) mengenai Majelis Pengawas Notaris disebutkan mempunyai kewenangan dan kewajiban untuk melaksanakan pembinaan dan pengawasan terhadap Notaris. Implikasi yuridis yang terjadi adalah adanya pertentangan norma antara ketentuan yang diatur dalam ketentuan Pasal 1 Angka (6), Pasal 66A dan pasal 67Undang-Undang No.2 Tahun 2014 tentang Perubahan atas Undang-Undang No.30 Tahun 2004. Dengan metode penelitian hukum normatif dengan pendekatanperundang-undangan (Statue Approach) dan Pendekatan Analisis Konsep Hukum (Analitical Conceptual Approach), penulis akan menganalisa ruang lingkup kewenangan keberadaan Majelis Pengawas Notaris dan Majelis Pengawas Notaris serta legalitas kewenangan fungsi Majelis Kehormatan Notaris dalam lembaga notariat sehingga tidak terjadi pertentangan kewenangan diantara kedua lembaga notariat te rsebut.

Kata Kunci : Implikasi yuridis, legalitas, kewenangan, Majelis Kehormatan Notaris.

\section{PENDAHULUAN}

\subsection{Latar Belakang}

Lahirnya profesi Notaris diawali dengan lahirnya profesi scribae pada zaman Romawi Kuno (Abad ke-II dan ke-III sesudah masehi) ${ }^{1}$. Di Indonesia,

${ }^{1}$ Anke Dwi Saputro, 2008, Jati Diri Notaris Indonesia Dulu, Sekarang, dan di Masa Datang, Gramedia Pustaka, Jakarta, hal. 40.
Notaris sudah dikenal semenjak zaman Belanda, ketika menjajah Indonesia. Istilah Notarispertama kali dikenal dengan istilah "Notarius Publicum" atau disebut juga "Notarius Publicus", yang dalam bahasa Romawi kata tersebut diberikan kepada orang-orang yang menjalankan pekerjaan menulis. Zaman kemerdekaan lembaga 
kenotariatan diakui keberadaannya berdasarkan asas konkordansi yang diatur dalam Reglement op Het Notaries Ambt in Nederlands Indie (staatsblad 1860 No.3) atau dikenal dengan Peraturan Jabatan Notaris. Lembaga Kenotariatan adalah salah satu lembaga kemasyarakatan di Indonesia, lembaga ini timbul dari kebutuhan dalam pergaulan sesama manusia yang menghendaki adanya suatu alat bukti mengenai hubungan hukum keperdataan yang ada dan atau terjadi diantara mereka ${ }^{2}$.Pada zaman reformasi staatsblad 1860 No.3 tersebut dicabut dimana lembaga jabatan notaris kemudian diatur dalam Undang-Undang No.30 Tahun 2004 yang selanjutnya untuk saat ini telah dirubah dengan Undang Undang No.2 Tahun 2014 (selanjutnya disebut dengan UUJN).

Kehadiran UUJN menjadi babak baru dalam dunia kenotariatan, dimana ada beberapa pasal yang merupakan perkembangan baru bagi pelaksanaan jabatan para notaris, salah satunya adalah bentuk pengawasan dan pembinaan yang dilakukan oleh lembaga pengawas notaris.Berdasarkan UUJN dalam pelaksanaan pengawasan tugas dan jabatan, notaris dalam hal ini dibina dan diawasi oleh Majelis Pengawas yang dibentuk oleh Menteri, sebagaimana diatur dalam Pasal 67 ayat (2) yang berbunyi: "Dalam melaksanakan pengawasan sebagaimana dimaksud pada ayat (1) Menteri membentuk Majelis Pengawas".

Dalam Pasal 1 angka (6) UUJN dijelaskan bahwa Majelis Pengawas

${ }^{2}$ G.H.S Lumban Tobing, 1999, Peraturan Jabatan Notaris, Erlangga, Jakarta, hal 2. adalah suatu badan yang kewenangan dan kewajiban untuk melaksanakan pembinaan dan pengawasan terhadap notaris. Dimana menurut Pasal 68 ayat (1) Majelis Pengawas terdiri atas Majelis Pengawas Daerah, Majelis Pengawas Wilayah, dan Majelis Pengawas Pusat.

Terkait dengan pengawasan dan pembinaan, sebelum adanya pengaturan lembaga pengawas notaris sebagaimana diatur dalam Undang-undang No.30 tahun 2004, pengawasan, pemeriksaan dan penjatuhan sanksi dilakukan oleh Badan peradilan yang berada di bawah Departemen Kehakiman sebagaimana pernah diatur dalam pasal 140 Regelement op de Rechtstelijke Organisatie en Het Der justitie (Stb. 1847 No. 23), pasal 96 Reglement Buitengewesten, pasal 3 Ordonantie Buitengerechtelijke VerrichtingenLembaran Negara 1946 Nomor 135 dan Pasal 50 Peraturan Jabatan Notaris. Pengawasan sebagaimana dimaksud kemudian berubah seiring perubahan kekuasaan kehakiman sebagimana yang diatur dalam Pasal 2 Undang-Undang No.4 tahun 2004 tentang Kekuasaan Kehakiman dan Pasal 1 Undang-Undang No.5 tahun 2004 tentang Mahkamah Agung. Perubahan kekuasaan kehakiman tersebut membawa perubahan pula pada pengalihan kewenangan pengawasan lembaga notaris.

Selain itu karena pada pasal 91 Undang-Undang No.30 tahun 2004(UUJN) telah mencabut dan menyatakan tidak berlaku lagi:

1). Reglement op Het Notaris Ambt in Indonesie (Stb 1860:3) sebagaimana telah 
diubah terakhir dalam Lembaran Negara Tahun 1945 Nomor 101;

2). Ordonantie 16 September 1931 tentang Honorarium Notaris;

3). Undang-Undang Nomor 33 Tahun 1954 tentang Wakil Notaris dan Wakil Notaris Sementara (Lembaran Negara Tahun 1954 Nomor 101, Tambahan Lembaran Negara Nomor 700);

4). Pasal 54 Undang-Undang Nomor 8 Tahun 2004 tentang Perubahan Atas UndangUndang Nomor 2 Tahun 1986 tentang Peradilan Umum (Lembaran Negara Republik Indonesia Tahun 2004 Nomor 34, Tambahan Lembaran Negara Republik Indonesia Nomor 4379); dan

5). Peraturan Pemerintah Nomor 11 Tahun 1949 tentang Sumpah/Janji Jabatan Notaris.

Maka secara otomatis sejak berlakunya UUJN pengawasan dan pembianaanyang semula dilakukan oleh lembaga peradilan dicabut dan diganti oleh UUJN dengan menciptakan lembaga baru yang disebut dengan Majelis Pengawas Notaris (selanjutnya disebut dengan MPN) yang terdiri dari Majelis Pengawas Pusat, Majelis Pengawas Wilayah dan Majelis pengawas Daerah, sebagaimana diatur dalam Pasal 67 UUJN.Disisi lain perkembangan saat ini, dengan diundangkannya UU Perubahan Atas UUJN yaitu Undang Undang No.2 Tahun 2014, muncul lembaga baru yang disebut Majelis Kehormatan Notaris (selanjutnya disebut MKN) yang mempunyai tugas melaksanakan pembinaan, sesuai dengan Pasal 66A ayat (1) yang berbunyi: "Dalam melaksanakan pembinaan Menteri membentuk Majelis Kehormatan Notaris".
Munculnya Majelis Kehormatan Notaris disini mengakibatkan terjadi tumpang tindih tugas dan wewenang antara Majelis Pengawas dan Majelis Kehormatan yang mana disini berdasarkan UU Perubahan Atas UUJN Pasal 1 angka (6) "Majelis Pengawas Notaris yang selanjutnya disebut Majelis Pengawas adalah suatu badan yang mempunyai kewenangan dan kewajiban untuk melaksanakan pembinaan dan pengawasan terhadap Notaris. Sedangkan disebutkan dalam Pasal 66A ayat (1), “Dalam melaksanakan pembinaan Menteri membentuk Majelis Kehormatan Notaris". Permasalahan yang muncul dikarenakan kurang adanya batasan yang jelas antara pembinaan yang dilakukan baik itu oleh Majelis Pengawas Notaris maupun Majelis Kehormatan Notaris. Hal ini ditambah dalam UU Perubahan Atas UUJN tidak terdapat penjelasan mengenai apa yang dimaksud dengan Majelis Kehormatan Notaris itu sendiri.

\subsection{Rumusan Masalah}

Berdasarkan latar belakang tersebut diatas maka hal-hal yang dapat dikaji sebagai berikut :

1. Bagaimanakah ruang lingkup kewenangan keberadaan Majelis Pengawas Notaris dan Majelis Pengawas Notaris?

2. Bagaimanakah legalitas kewenangan fungsi Majelis Kehormatan Notaris dalam lembaga notariat.

\subsection{Tujuan Penelitian}

Penelitian ini secara umum bertujuan untuk menyumbangkan pemikiran yang konsepsional mengenai, substansi, mekanisme, serta legalitas kewenangan yang dimiliki oleh Majelis 
Kehormatan Notaris sebagai pejabat publik dalam pelaksanaan tugas dan jabatan pengawasan dan pembinaan notaris. sedangkan secara khusus tujuan penelitian ini adalah:

1. Mengetahui dan memahami dasar kewenangan dari Majelis Kehormatan Notaris sebagaimana diatur dalam Undang-Undang No.2 Tahun 2014;

2. Mengetahui ruang lingkup kewenangan dan akuntabilitas kewenangan Majelis Kehormatan Notaris dalam melakukan pembinaaan dan pengawasan terhadap notaris dalam melakukan tugas dan jabatannya

3. Untuk mengetahui legalitas kewenangan Majelis Kehormatan Notaris dalam lembaga notariat

\subsection{Tinjauan Pustaka}

\subsubsection{Notaris Sebagai Pejabat Publik}

Dalam Pasal 1 angka 1 UndangUndang No. 30 Tahun 2004 tentang Jabatan Notaris disebutkan bahwa :

"Notaris adalah pejabat umum yang berwenang untuk membuat akta otentik dan kewenangan lainnya sebagaimana dimaksud dalam undang-undang ini."

Dalam pasal tersebut dapat dilihat bahwa Notaris merupakan pejabat umum yang diangkat, diberi wewenang dan kewajiban oleh Negara (pemerintah) untuk melayani publik khususnya dalam bidang pembuatan akta otentik. Dikarenakan jabatan Notaris diatur secara tersendiri dalam suatu Undangundang khusus, maka dapat disimpulkan bahwa jabatan Notaris bukanlah Pegawai Negeri sebagaimana dimaksud dalam Undang-Undang Nomor 8 Tahun 1974 jo Undang-Undang No 43 tahun
1999 Tentang Pokok Pokok

Kepegawaian yang sekarang sudah dicabut dan diganti dengan UndangUndang No.5 tahun 2014 tentang Aparatur Sipil Negara, walaupun Notaris diangkat dan disumpah oleh Negara (pemerintah).

Istilah Pejabat Umum merupakan terjemahan dari Bahasa Belanda yang disebut dengan Openbare Amtbtenaren dan istilah tersebut juga dituangkan dalam Peraturan Jabatan Notaris (Reglement op Het Notaris Ambt in Nederlands Indie (Staatblaad 1860:3)) yang menunjuk istilah tersebut sebagai sebutan Pejabat Umum. ${ }^{3}$ Pasal 1 Reglement op Het Notaris Ambt in Nederlands Indie, menyebutkan sebagai berikut :

De Notarissen zijn openbare ambtenaren, uitsluitend bevoegd, om authentieke akten op te maken wegens alle handelingen, overeenkomsten en beschikkingen, warvan eene algemeene verordening gebiedt of de belanghebbenden verlangen, dat bij authentiek geschrift blijken zal, daarvan de dagtekenig te verzekeren, de akten in bewaring te houden en daarvan grossen, afschrif akten en uittreksels uit te geven; alles voorzoover het opmaken dier akten door ene algemene verordening niet ook aan andere ambtenaren of personen opgedragen of voorbehouden is.

Terkait batasan yang dikemukakan oleh Sri Winari tersebut bahwa Pejabat umum mempunyai karakter yuridis yang berada dala kerangka hukum publik, maka pejabat umum yang dimaksud adalah sama dengan pejabat publik. Hal

${ }^{3}$ Lihat istilah Openbare Amtbtenaren yang terdapat dalam Art. 1 dalam Regelement op Het Notaris Ambt in Nederlands Indie (Ord. Van Jan. 1860) S.1860-3, diterjemahkan menjadi Pejabat Umum oleh G.H.S. Lumban Tobing, op.cit., h.5 
ini dikarenakan pejabat yang dimaksud mempunyai tugas yang berhubungan dengan pemenuhan kepentingan dari publik, sehingga tepat jika Openbare Ambtenaren diartikan sebagai Pejabat Publik.

Khusus berkaitan dengan Openbare Ambtenaren yang diterjemahkan sebagai Pejabat Umum, saat ini kualifikasi Pejabat Umum bukan hanya Notaris saja, melainkan ada juga Pejabat Pembuat Akta Tanah (PPAT), dan Pejabat Lelang. Namun Peran Notaris menjadi spesial karena notaris adalah pejabat umum yang telah ada sejak zaman penjajahan Belanda sebagai pejabat umum yang diberikan kewenangan khusus yang diatur oleh Undang-Undang untuk membuat akta otentik guna memberikan kepastian hukum serta melayani kepentingan publik dibidang perjanjian dalam lapangan hukum perdata.

\subsubsection{Timbulnya Wewenang Dan Kewenangan Notaris}

Dalam pengertian Hukum Tata Negara, kewenangan (authority, gezag) adalah kekuasaan yang diformalkan baik terhadap golongan orang tertentu maupun terhadap sesuatu bidang tertentu dalam pemerintahan.4Secara etimologis kata wewenang berasal dari kata dasar "wenang" yang merupakan terjemahan dari competentie (bahasa Inggris) atau bevouegheid serta gezag dari bahasa Belanda.5 Sejalan dengan pengertian tersebut dalam Fockema Andreal dinyatakan bahwa bevoegheid berarti wewenang. Sedangkan absolute bevoegheid berarti kekuasaan kehakiman

${ }^{4}$ SF. Marbun, 2003, Peradilan Administrasi Negara dan Upaya Administrasi di Indonesia, UII Press, Yogyakarta, h. 123.

${ }^{5}$ I Made Arya Utama, 2007, Hukum LingkunganSistem hukum Perizinan Berwawasan Lingkungan Untuk Pembangunan Berkelanjutan, Cet. 1, Pustaka Sutra, Bandung, h. 79 menentukan pengadilan mana yang berhak untuk menangani suatu perkara. Disebutkan pula bahwa bevoegheid sama artinya dengan competentie yakni wewenang, kekuasaan. ${ }^{6}$ Dengan demikian wewenang berarti identik dengan kekuasaan.

Dalam hal ini Van Maarseven sebagaimana disitir oleh Made Subawa, tidak membedakan antara wewenang (competence/bevoegheid) dengan kewenangan. Bagi Maarseven, wewenang dan kewenangan merupakan kekuasaan hukum (rechtsmacht). ${ }^{7}$ Disis lain dilihat dari cara memperoleh wewenang, menurut H.D Van Wijk bahwa wewenang oleh pemerintah diperoleh dengan tiga cara sebagai berikut :

a. Atribusi adalah pemberian wewenang pemerintah oleh pembuat undang-undang kepada suatu organ atau badan pemerintahan;

b. Delegasi adalah pelimpahan wewenang pemerintahan dari suatu organ pemerintahan kepada organ pemerintahan lainnya;

c. Mandat adalah terjadi ketika organ pemerintahan mengijinkan kewenangannya dijalankan oleh organ lain atas namanya. ${ }^{8}$

Berbeda dengan Van Wijk, F.A.M Stroink dan J.G Steenbeek menyebutkan bahwa hanya ada dua cara organ pemerintahan memperoleh wewenang, yaitu atribusi dan delegasi. Atribusi berkenaan dengan penyerahan penyerahan wewenang baru, sedangkan delegasi menyangkut pelimpahan wewenang yang telah ada (oleh organ yang telah memperoleh wewenang secara atributif kepada organ lain; jadi

${ }^{6}$ NE. Algra, H.R.W. Gokkel, Saleh Adiwinata, Boerhanoedin St. Batoeh, 1983, Kamus Istilah Hukum Belanda - Indonesia, Fockema Andreal Belanda, Binacipta, Jakarta, h. 74

${ }^{7}$ Saldi Isra, 2010, Pergeseran Fungsi Legislasi, Rajawali Pers, Jakarta, h. 11.

${ }^{8}$ Ridwan HR,2010, Hukum Administrasi Negara, Rajawali Pers, Jakarta, h. 108. 
delegasi secara logis selalu didahului oleh atribusi). ${ }^{9}$

Dalam kajian Hukum Administrasi Negara, mengetahui sumber dan cara memperoleh wewenang organ pemerintahan ini penting karena berkenaan dengan pertanggungjawaban hukum dalam penggunaan wewenang tersebut, seiring dengan salah satu prinsip negara hukum; yaitu tidak ada kewenangan tanpa pertanggungjawaban. Di dalam setiap pemberian kewenangan kepada pejabat pemerintahan tertentu tersirat pertanggungjawaban dari pejabat yang bersangkutan.

Berdasarkan keterangan tersebut diatas, tampak bahwa wewenang yang diperoleh secara atributif itu bersifat asli yang berasal dari peraturan perundang-undangan. Dengan kata lain, organ pemerintahan memperoleh kewenangan secara langsung dari redaksi pasal tertentu dalam suatu peraturan perundang-undangan. ${ }^{10}$ Dalam hal atribusi, penerima wewenang dapat menciptakan wewenang baru atau memperluas wewenang yang sudah ada dengan tanggung jawab intern dan ekstern pelaksanaan wewenang yang diatribusikan sepenuhnya berada pada peneriman wewenang (atributaris).Pada delegasi tidak ada penciptaan wewenang, namun hanya ada pelimpahan wewenang dari pejabat yang satu kepada pejabat lainnya.Tanggung jawab yuridis tidak lagi berada pada pemberi delegasi (delegans), tetapi beralih pada penerima (delegataris). Sementara itu, pada mandat, penerima mandat (mandataris) hanya bertindak untuk dan atas nama pemberi mandat ${ }^{9}$ Ibid, h.105.

${ }^{10}$ Ibid, h. 108. (mandans), tanggung jawab akhir keputusan yang diambil mandataris tetap berada pada mandat. ${ }^{11}$

Terkait dengan timbulnya wewenang sebagaimana dipaparkan diatas, kewenangan yang dimiliki oleh notaris selaku pejabat umum/publik adalah kewenangan yang bersifat atributif. Hal ini dikarenakan kewenangan yang timbul adalah kewenangan yang diatur dan diperoleh langsung dari undang-undang, khususnya Undang-undang No.30 tahun 2004 Tentang Jabatan Notaris sebagaimana saat telah dirubah dengan Undang-Undang No.2 Tahun 2014 Tentang Perubahan atasUndang-Undang No.30 tahun 2004 Tentang Jabatan Notaris

\subsubsection{Majelis Pengawas Notaris}

Terkait pengawasan Notaris dalam menjalankan tugas, fungsi dan jabatannya, Pasal 67 ayat 1 UUJN menentukan bahwa yang mempunyai kewenangan dalam melakukan pengawasan adalah mentri. Dalam melaksanakan pengawasan tersebut Menteri membentuk Majelis Pengawas (Pasal 67 ayat (2) UUJN) dengan beranggotakan orang-orang yang berasal dari unsur-unsur (Pasal 67 ayat (3) UUJN):

a Pemerintah sebanyak 3 (tiga) orang;

b Organisasi Notaris sebanyak 3 (tiga) orang; dan

c Ahli/ akademisi sebanyak 3 (tiga) orang. Menurut pasal 68 UUJN bahwa Majelis Pengawas Notaris terdiri atas :

a Majelis Pengawas Daerah;

b Majelis Pengawas Wilayah; dan

c Majelis Pengawas Pusat. Majelis Pengawas Daerah (MPD) dibentuk dan berkedudukan di Kabupaten atau Kota, Majelis Pengawas 
Wilayah (MPW) dibentuk dan berkedudukan di Ibukota Propinsi dan Majelis Pengawas Pusat (MPP) dibentuk dan berkedudukan di Ibukota Negara. Secara Garis besar Majelis Pengawas Notaris secara umum mempunyai ruang lingkup kewenangan yang diatur dalam Pasal 63, Pasal 67, Pasal 69, 70 huruf a, Pasal 73 ayat (1) huruf a dan b, Pasal 77 huruf a dan b , Pasal 78 dan Pasal 79 UUJN (UU No.30 Tahun 2204 dan perubahannya UU No.2 Tahun 2014).Majelis Pengawas Notararis tidak hanya mempunyai kewenangan di bidang pengawasan, namun berwenang pula melakukan pemeriksaan dan penjatuhan sanksi tertentu terhadap Notaris yang telah terbukti melakukan pelanggaran atau perbutan melawan hukum dalam menjalankan tugas jabatannya. Pengawas Notaris dalam menjalankan tugas, fungsi dan kewenangannya selain berpedoman pada UUJN, juga berpedoman pada peraturan berikut ini:

1. Peraturan Menteri Hukum Dan Hak Asasi Manusia RI Nomor : M.02.PR.08.10 Tahun 2004 Tentang Tata Cara Pengangkatan Anggota, Susunan Organisasi, Tata Kerja, Dan Tata Cara Pemeriksaan Majelis Pengawas Notaris

2. Keputusan Menteri Hukum dan Hak Asasi Manusia RI Nomor : M39-PW.07.10 Tahun 2004 Tentang Pedoman Pelaksanaan Tugas Majelis Pengawas Notaris

\section{METODE PENELITIAN}

Penelitian yang penulis gunakan adalah penelitian hukum Normatif. Penelitian hukum normatif yaitu penelitian yang menguraikan terhadap permasalahan-permasalahan yang ada, untuk selanjutnya dibahas dengan kajian teori-teori hukum kemudian dikaitkan dengan peraturan perundang-undangan yang berlaku dalam praktek hukum. ${ }^{12}$ Dalam penelitian ini permasalahan yang adadikaji dan diuraikan dengan jalan menganalisa menggunakan berbagai teori hukum serta melalui penelusuran dan interpretasi dari aturan-aturan hukum yang terkait dengan permasalahan yang ada. Jenis pendekatan yang digunakan diantaranya adalah Pendekatan Perundang-undangan (Statue Approach)dan Pendekatan Analisis Konsep Hukum(Analitical Conceptual Approach). Dengan teknik pengumpulan data kepustakaan, data yang diperoleh dianalisis berdasarkan metode kualitatif selanjutnya disajikan secara deskriptif analitis.

\section{HASIL DAN PEMBAHASAN}

\subsection{Majelis Kehormatan Notaris dalam Lembaga Notariat}

Majelis Kehormatan Notaris merupakan lembaga baru yang dihadirkan oleh Lembaga notariat dalam Undang-Undang No. 2 Tahun 2014 Tentang Perubahan atas Undang-Undang No.30 Tahun 2004 Tentang Jabatan Notaris. Sebagai lembaga baru Majelis Kehormatan Notaris telah memberi warna baru dalam pembinaan notaris yang ada di Indonesia, sudah sepantasnya diberikan ruang khusus berdampingan dengan lembaga lembaga lainnya dalam lembaga notariat guna mendukung pelaksanaan jabatan notaris yang bersih dan profesional.

Lembaga Majelis Kehormatan Notaris tidak muncul seketika, namun melalui proses kebijakan yang kemudian secara lebih lanjut dicantumkan

${ }^{12}$ Soerjono Soekanto dan Sri Mamudji, 2001, Penelitian Hukum Normatif Suatu Tinjauan Singkat, edisi I Cetakan V, PT Raja Grafindo Persada Jakarta, h. 13. 
secara tegas dalam Undang-undang no. 2 Tahun 2014. Untuk diketahui bersama bahwa proses terbentuknya lembaga majelis kehormatan tersebut diawali dengan adanya permohonan uji materiil (judicialreview) terhadap Pasal 66 (ayat (1) UU No.30 Tahun 2004 tentang Jabatan Notaris yang diajukan Kant Kamalkarena dianggap bertentangan dengan UUD 1945 dan tidak memiliki kekuatan hukum mengikat. Kemudian atas uji materiil tersebut MK mengabulkan dengan putusan No. 49/PUUX/2012 tanggal 23 Maret 2013. Dalam Amar putusan tersebut MK membatalkan frasa dengan persetujuan Majelis Pengawas Daerah (MPD) sebagaimana diatur dalam pasal 66 (ayat (1) UU No.30 Tahun 2004. Sehingga dengan demikian pemeriksaan proses hukum yang melibatkan notaris tidak memerlukan persetujuan MPD lagi.

Keputusan ini bersifat final, mengikat dan harus ditaati.

Sebelum perubahan Pasal 66 dalam UndangUndang No 30 Tahun 2004 tentang Jabatan Notaris menyatakan bahwa :

(1) Untuk kepentingan proses peradilan, penyidik, penuntut umum, atau hakim dengan persetujuan Majelis Pengawas Daerah berwenang:

a. Mengambil fotokopi Minuta Akta dan/atau surat-surat yang dilekatkan pada Minuta Akta atau Protokol Notaris dalam penyimpanan Notaris; dan

b. Memanggil Notaris untuk hadir dalam pemeriksaan yang berkaitan dengan akta yang dibuatnya atau Protokol Notaris yang berada dalam penyimpanan Notaris.

\section{Sebelum adanya Putusan MK,}

Notaris tidak bisa masuk dalam proses peradilan untuk menghadap penyidik, penuntut umum dan/ atau hakim tanpa adanya persetujuan dari Majelis Pengawas Daerah. Penegak hukum terutama polisi tidak bisa langsung demi proses peradilan pidana mengambil dokumen dalam penyimpanan Notaris dan memangil
Notaris untuk hadir dalam pemeriksaan, tanpa adanya persetujuan dari MPD. Pasal 66 Undang-Undang No 30 Tahun 2004 tersebut dianggap telah melanggar prinsip persamaan di depan hukum (equality before the law) yang tersirat dalam Pasal 28 ayat (1) UUD 1945 sesuai dengan Article 26 ICCPR (International Covenant onCiviland Political Rights) 1966 yang sudah diratifikasi oleh Indonesia dengan UU No.12/2005. Di sini ditegaskan adanya persamaan kedudukan semua orang di depan hukum dan hak semua orang atas perlindungan hukum yang sama (equal protection) tanpa adanya diskriminasi. Menurut MK, ada prinsip demokrasi dan rule of law yang bisa dilanggar dengan frasa tersebut di atas, yaitu kekuasaan kehakiman yang merdeka. Ikut sertanya MPD juga dianggap bisa menimbulkan penundaan proses peradilan dan keadilan (justicedelayed justice denied). Sementara penundaan keadilan juga melanggar HAM (delay of justice isviolation of human rights). Perkecualian tentu saja dimungkinkan terhadap kedudukan Notaris sepanjang berkaitan dengan Kode Etik Notaris yang bersentuhan dengan sikap, tingkah laku dan moralitas serta kehormatan Notaris, bukan dalam penegakan hukum, khususnya sistem peradilan pidana (criminal justice system $)^{13}$.

Menyikapi putusan Mahkamah Konstitusi tersebut kemudian pemerintah melalui Menteri Hukum dan Hak Asasi Manusia mengadakan perubahan terhadap Undang-Undang

${ }^{13}$ http://medianotaris.com/pasca_putusan_m k kalau benar dan taat hukum mengapa resah berita304.html 
No.30 Tahun 2004 dengan UndangUndang No. 2 Tahun 2014.

Dalam Undang-Undang yang baru tersebut kewenangan untuk memberikan persetujuan pemanggilan Notaris tidak dapat dilakukan lagi oleh Majelis Pengawas Daerah. Namun jika dicermati di dalam Pasal 66 muncul lembaga yang berbeda yaitu Majelis Kehormatan Notaris. Berdasarkan perubahan Pasal 66 tersebut dimana kewenangan Majelis Pengawas Daerah dalam memberikan persetujuan terhadap pemerikasaan Notaris oleh penegak hukum tidak berlaku lagi diganti dengan kewenangan Majelis Kehormatan Notaris. Diantara Pasal 66 dan Pasal 67 ada pasal yang disisipkan, yakni Pasal 66A yang mengatur tentang Majelis Kehormatan Notaris. Lembaga ini seakan mengganti kewenangan yang semula dimiliki oleh Majelis Pengawas Daerah, yang sebelumnya MPD sebagaimana pasal 1 angka 6 Undang-Undang No 30 tahun 2004 menyatakan "Majelis Pengawas adalah suatu badan yang mempunyai kewenangan dan kewajibanuntuk melaksanakan pembinaan dan pengawasan terhadap Notaris". Maka pertanyaan yang timbul adalah apakah kewenangan yang dimiliki Majelis Kehormatan Notaris ini sama dengan Majelis Pengawas yaitu pembinaan dan pengawasan terhadap notaris sebagai pejabat publik dalam menjalankan kode etiknya?.

Jika kita lihat dari pasal 66 dan pasal 66 A Undang-Undang No.2 Tahun 2014 maka kedudukan antara Majelis Pengawas dengan Majelis Kehormatan adalah sama, yaitu sama-sama mewakili menteri Hukum dan hak Asasi Manusia dengan kewenangan yang bersifat atributif, dimana untuk kewenangan Majelis pengawas adalah mengadakan pembinaan dan pengawasan terhadap notaris sedangkan untuk Majelis Kehormatan kewenangannya adalah mengadakan pembinaan notaris sebagai pejabat publik dalam menjalankan kode etik profesinya. Terkait hal tersebut perlu ketegasan pembatasan kewenangan yang dituangkan dalam peraturan pelaksana serta perlu adanya stratifikasi secara hirarki dalam lingkup kewenangan, agar para pihak yang berkepentingan langsung dengan tugas fungsi notaris selaku pejabat publik tidak kebingungan dan seakan-akan profesi notaris merupakan profesi yang eksklusif yang tidak bisa tersenuh (untuchable profession) oleh hukum, apabila terjadi kasus penyalahgunaan wewenang oleh notaris.

3.2 Ruang Lingkup Kewenangan Majelis

Kehormatan Notaris dan Majelis Pengawas Notaris

Majelis Pengawas Notaris merupakan bagian dari lembaga notariat yang mana dalam pasal 1 angka 6 Undang-Undang No.30 Tahun 2004 Jo. Undang-Undang No.2 tahun 2014 tentang Jabatan Notaris merupakan suatu badan yang mempunyai kewenangan dan kewajiban untuk melaksanakan pembinaan dan pengawasan terhadap Notaris yang meliputi perilaku dan pelaksanaan jabatan Notaris. Secara Garis besar Majelis Pengawas Notaris secara umum mempunyai ruang lingkup kewenangan yang diatur dalam Pasal 63, Pasal 67, Pasal 69, 70 huruf a, Pasal 73 ayat (1) huruf a dan b, Pasal 77 huruf a dan b, 
Pasal 78 dan Pasal 79 UUJN (UU No.30

Tahun 2204 dan perubahannya UU No.2

Tahun 2014). Disamping itu mengenai

Tata Cara Pengangkatan Anggota,

Susunan Organisasi, Tata Kerja,

Pedoman Kerja serta Tata Cara

Pemeriksaan Majelis Pengawas Notaris diatur secara khusus dan terperinci dalam Keputusan Menteri Hukum dan

Hak Asasi Manusia RI Nomor : M39PW.07.10 Tahun 2004 dan Peraturan Menteri Hukum Dan Hak Asasi Manusia RI Nomor: M.02.PR.08.10 Tahun 2004.

$$
\text { Majelis Kehormatan notaris }
$$
sebagaimana lembaga notariat yang baru muncul setelah diadakannya perubahan UUJN dengan undang-Undang No.2 Tahun 2014, terkait ruang lingkup yang dimiliki diatur dalam Pasal 66 dan 66 Huruf A yang menyatakan sebagai berikut :

\section{Pasal 66}

(1) Untuk kepentingan proses peradilan, penyidik, penuntut umum, atau hakim dengan persetujuan majelis kehormatan Notaris berwenang:

a. Mengambil fotokopi Minuta Akta dan/atau surat-surat yang dilekatkan pada Minuta Akta atau Protokol Notaris dalam penyimpanan Notaris; dan

b. Memanggil Notaris untuk hadir dalam pemeriksaan yang berkaitan dengan Akta atau Protokol Notaris yang berada dalam penyimpanan Notaris.

(2) Pengambilan fotokopi Minuta Akta atau surat-surat sebagaimana dimaksud pada ayat (1) huruf a,dibuat berita acara penyerahan.

(3) Majelis kehormatan Notaris dalam waktu paling lama 30 (tiga puluh) hari kerja terhitung sejak diterimanya surat permintaan persetujuan sebagaimana dimaksud pada ayat (1) wajib memberikan jawaban menerima atau menolak permintaan persetujuan.

(4) Dalam hal majelis kehormatan Notaris tidak memberikan jawaban dalam jangka waktu sebagaimana dimaksud pada ayat (3), majelis kehormatan Notaris dianggap menerima permintaan persetujuan."

Pasal 66A

(1) Dalam melaksanakan pembinaan, Menteri membentuk majelis kehormatan Notaris.

(2) Majelis kehormatan Notaris berjumlah 7 (tujuh) orang, terdiri atas unsur:

a. Notaris sebanyak 3 (tiga) orang;

b. Pemerintah sebanyak 2 (dua) orang; dan

c. ahli atau akademisi sebanyak 2 (dua) orang.

(3) Ketentuan lebih lanjut mengenai tugas dan fungsi, syarat dan tata cara pengangkatan dan pemberhentian, struktur organisasi, tata kerja, dan anggaran majelis kehormatan Notaris diatur dengan Peraturan Menteri."

Jika kita kaji dari bunyi pasal 66 dan Pasal 66A tersebut diatas maka, dapat dilihat bahwa Majelis Kehormatan Notaris diisyaratkan untuk dibentuk dengan kewenangan untuk pembinaan guna membantu Menteri Hukum dan HAM dalam upaya melakukan pembinaan terhadap Notaris sebagai pejabat publik terkait dengan adanya kepentingan proses peradilan, penyidikan, tuntutan hukum baik oleh polisi, jaksa selaku penuntut umum atau hakim. Dalam hal ini terjadi maka Majelis Kehormatan Notaris dapat mengambil keputusan untuk memberikan persetujuan atau tidak terkait dengan permintaan pemanggilan notaris serta pemeriksaan fotokopi Minuta Akta dan/atau surat-surat yang dilekatkan pada Minuta Akta atau Protokol Notaris yang ada dalam penyimpanan Notaris.

Terkait mengenai lingkup kewenangan Majelis Kehormatan Notaris tersebut, ada beberapa hal menjadi fokus pertanyaan dan perlu dibahas yaitu apakah Majelis 
Kehormatan Notaris sebagaimana dimaksud sama dengan Dewan

Kehormatan Notaris Ikatan Notaris Indonesia (INI)?

Untuk diketahui bahwa Dewan

Kehormatan Notaris INI adalah lembaga internalINI yang mandiri dan bebas dari keberpihakan dalam Perkumpulan yang bertugas untuk :

- Melakukan pembinaan, bimbingan, pengawasan, pembenahan anggota dalam menjunjung tinggi kode etik;

- Memeriksa dan mengambil keputusan atas dugaan pelanggaran ketentuan kode etik yang bersifat internal atau yang tidak mempunyai kaitan dengan kepentingan masyarakat secara langsung;

- Memberikan saran dan pendapat kepada Majelis Pengawas atas dugaan pelanggaran Kode Etik dan jabatan Notaris

Dewan Kehormatan INI dibentuk didalam pekumpulan INI hanya mempunyai kewenangan penegakan kode etik kedalam perkumpulan saja. Sangat jelas hal ini berbeda dengan Majelis Kehormatan Notaris yang ada dan dibentuk oleh Menteri Hukum dan HAM yang bertugas membantu Menteri terkait kewenangan Pembinaan terhadap notaris selaku pejabat publik.

Hal lain terkait keberadaan Majelis Kehormatan Notaris adalah adanya pertentangan norma sebagaimana diatur dalam Pasal 1 Angka 6 dengan Pasal 66A Undang-Undang No.2 Tahun 2014 tentang Perubahan atas Undang-Undang No.30 Tahun 2004. Dalam ketentuan pasal 1 angka 6 tersebut kewenangan Majelis Pengawas mempunyai 2 (dua) kewenangan yaitu pengawasan dan pembinaan, yang bertolak belakang dengan ketentuan pasal 67Undang-
Undang No.2 Tahun 2014 tentang Perubahan atas Undang-Undang No.30 Tahun 2004. Sedangkan kewenangan pembinaan oleh Majelis Kehormatan Notaris sebagaimana diatur dalam pasal 66A juga dimiliki oleh Majelis Pengawas Notaris sebagaimana disebutkan dalam pasal 1 angka 6 tersebut. Pertentangan norma ini menyebabkan kekaburan norma terkait wilayah kewenangan pembinaan mana yang dimiliki oleh Majelis Pengawas tersebut. Dalam ini perlu penjelasan lebih lanjut dalam penjelasan umum Undang-Undang No.2 Tahun 2014, tapi dalam kenyataannya hal tersebut tidak ada. Oleh sebab itu, saran penulis sebaiknya perlu perubahan terhadap Undang-Undang terkait.

Disamping itu mengenai kewenangan pembinaan notaris selaku pejabat publikterkait dengan adanya kepentingan proses peradilan, penyidikan, tuntutan hukum baik oleh polisi, jaksa selaku penuntut umum atau hakim oleh Majelis Kehormatan sebagaimana perintah Pasal 66A Ayat(3), untuk pengaturan lebih lanjut dalam Peraturan Menteri tentang tugas dan fungsi, syarat dan tata cara pengangkatan danpemberhentian, struktur organisasi, tata kerja, dan anggaran majelis kehormatan Notaris sebaiknya segera di laksanakan. Dal ini ditujukan agar tidak ada lagi kekaburan norma terkait wilayah kewenangan dari Majelis Kehormatan Notaris. Disisi lain Keputusan Menteri Hukum dan Hak Asasi Manusia RI Nomor : M39PW.07.10 Tahun 2004 dan Peraturan Menteri Hukum Dan Hak Asasi Manusia RI Nomor : M.02.PR.08.10 Tahun 2004 
yang telah ada, perlu ditinjau lebih lanjut untuk segera diadakan perubahan terkait dengan munculnya Lembaga Majelis Kehormatan Notaris, agar tidak terjadi tumpang tindih kewenangan antara Majelis Pengawas.

\subsection{Legalitas Kewenangan Majelis \\ Kehormatan Notaris}

Asas legalitas merupakan salah satu prinsip utama yang dijadikan dasar dalam setiap penyelenggaraan pemerintahan dan kenegaraan di setiap negara hukum terutama bagi negaranegara hukum dalam sistem kontinental. Menurut S. F Marbun asas legalitas adalah salah satu asas dalam negara hukum demokrasi dimana wewenang atau kekuasaan administrasi negara diperoleh atas dasar Undang- undang. ${ }^{14}$ Hukum Pidana dan Hukum Administrasi Negara juga mengenal adanya asas legalitas, karena asas ini merupakan sendi utama penyelenggaraan kenegaraan dan pemerintahan yang sifatnya sentral sebagai suatu fundamen dari negara hukum. Secara normatif, prinsip bahwa setiap tindakan pemerintah harus berdasarkan peraturan perundang-undangan atau berdasarkan kewenangan dianut oleh setiap negara hukum, namun dalam praktiknya penerapan prinsip ini berbeda-beda antara satu negara dan negara lain.

Negara hukum menuntut agar penyelenggaraan urusan kenegaraan dan pemerintahan harus didasarkan pada undang-undang yang dapat memberikan jaminan terhadap hak-hak dasar rakyat,

${ }^{14}$ Marbun, S.F., 2001, Menggali dan Menemukan Asas-asas Umum Pemerintahan Yang Baik di Indonesia (Dimensi-Dimensi Pemikiran Hukum Administrasi Negara), UII Press, Yogyakarta, hal.211. dan dalam hal ini asas legalitaslah yang menjadi dasar legitimasi tindakan pemerintahan dan jaminan perlindungan dari hak-hak rakyat. Menurut Sjachran Basah, asas legalitas berarti upaya mewujudkan duet integral secara harmonis antara paham kedaulatan hukum dan paham kedaulatan rakyat berdasarkan prinsip monodualistis selaku pilar-pilar, yang sifat hakikatnya konstitutif. ${ }^{15}$

Penerapan asas legalitas, akan menunjang berlakunya kepastian hukum dan kesamaan perlakuan. Kesamaan perlakuan terjadi karena setiap orang yang berada dalam situasi yang ditentukan dalam ketentuan undangundang itu berhak dan berkewajiban untuk berbuat seperti apa yang ditentukan undang-undang itu. Sementara itu, kepastian hukum akan terjadi karena suatu peraturan dapat membuat semua tindakan yang akan dilakukan pemerintah itu dapat diramalkan atau diperkirakan terlebih dahulu, dengan melihat pada peraturanperaturan yang berlaku, maka pada asasnya lalu dapat dilihat atau diharapkan apa yang akan dilakukan oleh aparat pemerintah yang bersangkutan. Dengan demikian, warga masyarakat lalu dapat menyesuaikan dengan keadaan tersebut ${ }^{16}$.

Disamping itu, H.D. Stout dalam bukunya Ridwan, Hukum Administrasi Negara mengatakan "Het

\section{${ }^{15}$ Sjachran, $\quad$ Basah., 1992,} Perlindungan Hukum Atas Sikap Tindak administrasi Negara, Alumni, Bandung, hal.2.

${ }^{16}$ Indroharto., 1993, Usaha Memahami Undang-Undang Tentang Peradilan Tata Usaha Negara buku ke I, Pustaka Sinar harapan, Jakarta, hal. 83-84. 
legaliteitsbeginsel beoogt de rechtpositie van de burger jegens de overheid te warborgen" yaitu asas legalitas dimaksudkan untuk memberikan jaminan kedudukan hukum warga negara terhadap pemerintah dimana pemerintah hanya dapat melakukan perbuatan hukum jika memiliki legalitas atau didasarkan pada undang-undang yang merupakan perwujudan aspirasi warga negara ${ }^{17}$. Dalam negara hukum demokratis, tindakan pemerintah hanya mendapatkan legitimasi dari rakyat yang secara formal tertuang dalam undang-undang.

Terkait konsep asas legalitas tersebut notaris selaku pejabat publik dalam melaksanakan fungsi jabatannya dalam membuat akta otentik didasarkan atas Undang-Undang jabatan yang berfungsi untuk memberikan kepastian hukum dalam setiap hubungan hukum dalam masyarakat. Undang-Undang jabatan sebagaimana dimaksud saat ini diatur dalam Undang-Undang No. 2 Tahun 2014 tentang perubahan atas UndangUndang No.30 Tahun 2004 tentang Jabatan Notaris. Jika dilihat dari sejarah keberadaannya di Indonesia Notaris merupakan profesi yang ada sejak jaman penjajahan Belanda, dimana pada waktu itu profesi notaris yang disebut juga "Notarium Publicum" bertugas melayani guna melakukan pencatatan keperluan para penduduk dan para pedagang seperti pembuatan surat wasiat di bawah tangan, kontrak perdagangan, perjanjian kawin, serta akta -akta lainnya. Sebagai negara yang pernah dijajah maka sistem hukum yang berlaku sebagai dasar hukum pelaksanaan tugas fungsi notaris adalah warisan dari pemerintah kolonial belanda yang berdasarkan atas asas Konkordansi berlaku di Indonesia.

${ }^{17}$ Ridwan, H.R., 2006, Hukum Administrasi Negara, PT. Raja Grafindo Persada, Jakarta, hal.97-98.
Adapun produk peraturan perundangundangan yang mengatur legalitas kewenangan tugas dan fungsi notaris sebelum berlakunya Undang-undang No.2 tahun 2014 tentang Perubahan atas Undang-Undang No.30 Tahun 2004 tentang Jabatan Notaris, adalah :

1). Reglement Op Het Notaris Ambt in Indonesie (Stb.1860:3) sebagaimana telahdiubah terakhir dalam Lembaran Negara Tahun 1954 Nomor 101;

2). Ordonantie 16 September 1931 tentang Honorarium Notaris;

3). Undang-Undang Nomor 33 Tahun 1954. tentang Wakil Notaris dan Wakil NotarisSementara (Lembaran Negara Tahun 1954 Nomor 101, Tambahan Lembaran Negara Nomor 700);

4). Undang-Undang Nomor 8 Tahun 2004 tentang Perubahan Atas UndangundangNomor 2 Tahun 1986 tentang Peradilan Umum (Lembaran Negara Republik Indonesia Tahun 2004 Nomor 34, Tambahan Lembaran Negara Republik IndonesiaNomor 4379); dan

5). Peraturan Pemerintah Nomor 11 Tahun 1949 tentang Sumpah/Janji Jabatan Notaris.

Peraturan yang berlaku tersebut diatas sebagian besar masih didasarkan atas peraturan perundang-undangan zaman kolonial dan sebagian lagi merupakan peraturan perundangundangan nasional. Peraturan perundang-undangan tersebut dianggap tidak lagi sesuai dengan perkembangan zaman sehingga berdasarkan pasal $91 \mathrm{ke}$ 5 peraturan perundang-undangan tersebut dicabut dan diganti dengan Undang-Undang No. 30 tahun 2004 sebagaimana kemudian telah dirubah menjadi Undang-Undang No.2 Tahun 2014 tentang Jabatan Notaris. 
Dalam Undang-Undang Jabatan Notaris saat ini ada 2 lembaga notariat yaitu Majelis Pengawas Notaris dan Majelis Kehormatan Notaris. Kewenangan khusus untuk Majelis Pengawas Notaris diatur dalam Pasal 63, Pasal 67, Pasal 69, 70 huruf a, Pasal 73 ayat (1) huruf a dan b, Pasal 77 huruf a dan b, Pasal 78 dan Pasal 79 UUJN (UU No.30 Tahun 2204 dan perubahannya UU No.2 Tahun 2014). Disamping itu mengenai Tata Cara Pengangkatan Anggota, Susunan Organisasi, Tata Kerja, Pedoman Kerja serta Tata Cara Pemeriksaan Majelis Pengawas Notaris diatur secara khusus dan terperinci dalam Keputusan Menteri Hukum dan Hak Asasi Manusia RI Nomor: M39-PW.07.10 Tahun 2004 dan Peraturan Menteri Hukum Dan Hak Asasi Manusia RI Nomor : M.02.PR.08.10 Tahun 2004. Sebagai bagian dari lembaga notariat yang ada Majelis Pengawas Notaris telah mempunyai dasar hukum yang kuat dalam menjalankan tugasnya dan dari sejumlah pengaturan peraturan tersebut dapat disimpulkan bahwa Majelis Pengawas Notaris mempunyai kewenangan dalam melakukan pengawasan, pemeriksaan dan penjatuhan sanksi. Namun hal tersebut tidak serta merta membuat legalitas Majelis Pengawas Notaris kuat, hal ini dapat dilihat dari adanya gugatan di Mahkamah Konstitusi terkait kewenangan dari Majelis Pengawas Daerah dalam proses peradilan sebagaiamana diatur dalam pasal 66 Undang-undang No.30 Tahun 2004 tentang Jabatan Notaris.Hasil keputusan terkait pengajuan gugatan tersebut adalah dibatalkannya Pasal 66 tersebut dimana Mahkamah Konstitusi menyatakan proses peradilan guna mengambil dokumen dalam penyimpanan notaris dan memanggil notaris untuk hadir dalam pemeriksaan yang berkaitan dengan dokumen-dokumen yang dibuatnya tidak perlu meminta persetujuan MPD. Prosedur persetujuan itu dinilai bertentangan dengan prinsipequal protection sebagaimana yang dijamin UUD $1945^{18}$.

Setelah dibatalkannya pasal tersebut, Menteri Hukum dan HAM menindaklanjutinya dengan mengadakan perubahan Undang-Undang No.30 Tahun 2004 dengan mengundangkan UndangUndang No.2 tahun 2014 pada tanggal 15 Januari 2014. Namun kontrofersi yang terjadi adalah pasal 66 yang dirubah dalam Undang-Undang No.2 tahun 2014 tersebut memunculkan lembaga baru dari Majelis Pengawas daerah menjadi Majelis Kehormatan Notaris. Pasal 66 ini hanya mengganti lembaga yang berwenang memberikan persetujuan dalammemanggil Notaris untuk hadir dalam pemeriksaan serta mengambil fotokopi Minuta Akta dan/atau surat-surat yang dilekatkan pada Minuta Akta atau Protokol Notaris yang ada dalam penyimpanan Notaris. Ibarat hanya ganti baju, apa yang menjadi pertimbangan dalam diktum putusan Mahkamah Konstitusi tidak menjadi hal mendasar dalam perubahan Undang-Undang No.30 Tahun 2004 tersebut. Nilai-nilai equal protection kepada semua warga negara, prinsip

${ }^{18} \mathrm{http}: / / w w w . h u k u m o n l i n e . c o m /$ berita/baca/lt 51a4b3374d208/pemeriksaan-notaris-tak-perlupersetujuan-mpd. 
demokrasi dan rule of law darikekuasaan kehakiman yang merdeka seakan tidak diindahkan dengan adanya frasa "dengan persetujuan". Padahal keinginan dari pihak yang nengajukan gugatan ke MK tersebut adalah menghapuskan startifikasi lembaga notariat dalam melindungi notaris dari kepentingan umum terkait adanya tindak pidana yang dilakukan oleh pejabat notaris.

Disisi lain adanya lembaga Majelis Kehormatan notaris membawa warna baru yang perlu mendapatkan ketegasan bahwa ada beberapa hal yang perlu diatur secara lebih lanjut, sebagaimana yang diperintahkan dalam pasal 66 A ayat (3) terkait ketentuan lebih lanjut mengenai tugas dan fungsi, syarat dan tata cara pengangkatan danpemberhentian, struktur organisasi, tata kerja, dan anggaran majelis kehormatan Notaris yang diaturdengan Peraturan Menteri. Walaupun secara legalitas (Rechtmatigheid) kewenangan yang dimiliki oleh Majelis Kehormatan Notaris sah, karena bersumber dari Undang-Undang No.2 Tahun 2014 yang merupakan kewenangan yang bersifat atributif, namun dalam pelaksanaan kewenangan tersebut perlu adanya beberapa peraturan yang mendukung sebagai panduan serta arahan dalam pelaksanaan kebijakan agar tidak terjadi penyalahgunaan wewenang. Peraturan lebih lanjut mengenai pengaturan dari kewenagan majelis Kehormatan Notaris selain berfungsi sebagai arahan dasar pelaksanan kewenangan, dalam hukum administrasi negara peraturan tertulis tersebut dapat berfungsi sebagai alat untuk menguji suatu keabsahan tidakan serta kebijakan yang dibuat oleh Pejabat/ Badan administrasi Negara khususnya Majelis Kehormatan Notaris tersebut.

Setelah adanya Majelis Kehormatan Notaris untuk mengganti kewenangan yang semula dimiliki oleh Majelis Pengawas Daerah (MPD), mensyaratkan adanya perubahan terhadap ruang lingkup kewenangan masing masing lembaga notariat tersebut. Sebagaimana diketahui bahwa kewenangan Majelis Pengawas Notaris selain diatur dalam Undang-Undang No.2 tahun 2014 Tentang Perubahan atas Undang-Undang No.30 Tahun 2004 Tentang jabatan Notaris, Kewenangan tersebut diatur juga dalam Peraturan Menteri Hukum Dan Hak Asasi Manusia RI Nomor : M.02.PR.08.10 Tahun 2004 Tentang Tata Cara Pengangkatan Anggota, Susunan Organisasi, Tata Kerja, Dan Tata Cara Pemeriksaan Majelis Pengawas Notaris dan Keputusan Menteri Hukum dan Hak Asasi Manusia RI Nomor : M39-PW.07.10 Tahun 2004 Tentang Pedoman Pelaksanaan Tugas Majelis Pengawas Notaris. Apabila nantinya peraturan lanjutan yang mengatur kewenangan Majelis Kehormatan Notaris telah diundangkan sebagaimana perintah dari Pasal 66 A ayat (3), maka secara langsung akan mengurangi kewenangan yang semula dimiliki oleh Majelis Pengawas Notaris, sehingga sudah seharusnya peraturanperaturan tersebut diatas dirubah/ disesuaikan dengan perkembangan hukum yang ada. Walaupun secara tegas bahwa lingkup kewenangan baik Majelis Pengawas di bidang pengawasan yang diatur dalam pasal 67 ayat (2) dan 
Majelis Kehormatan Notaris di bidang pembinaan sebagaimana yang diatur dalam Pasal 66 A ayat (1)UndangUndang No.2 Tahun 2014, tetap diperlukan adanya pengaturan lebih lanjut yang lebih tegas agar tidak terjadi pertentangan norma dan tumpang tindih kewenangan diantara kedua lembaga notariat tersebut. Sehingga dalam hal ini penulis menyimpulkan bahwa perlu segera melaksanakan perintah Undang-Undang No.2 Tahun 2014, secara umum sebagaimana tertuang dalam Pasal 91B dan secara khusus mengenai Majelis Kehormatan Notaris dalam Pasal 66A ayat (3).

\section{KESIMPULAN DAN SARAN}

\subsection{Kesimpulan}

1. Implikasi yuridis yang terjadi terkait ruang lingkup keberadaan Majelis Kehormatan Notaris adalah adanya pertentangan norma diantara ketentuan sebagaimana diatur dalam Pasal 1 Angka 6 dengan Pasal 66A Undang-Undang No.2 Tahun 2014 tentang Perubahan atas UndangUndang No.30 Tahun 2004. Dalam ketentuan pasal 1 angka 6 tersebut kewenangan Majelis Pengawas mempunyai 2 (dua) kewenangan yaitu pengawasan dan pembinaan, yang bertolak belakang dengan ketentuan pasal 67 Undang-Undang No.2 Tahun 2014 tentang Perubahan atas Undang-Undang No.30 Tahun 2004. Sedangkan kewenangan pembinaan oleh Majelis Kehormatan Notaris sebagaimana diatur dalam pasal 66A juga dimiliki oleh Majelis Pengawas Notaris sebagaimana disebutkan dalam pasal 1 angka 6 tersebut.
Disi lain tidak dicantumkan mengenai apa yang dimaksud majelis kehormatan notaris dalam ketentuan umum menimbulkan adanya kekaburan norma.

2. Secara legalitas (Rechtmatigheid) kewenangan yang dimiliki oleh Majelis Kehormatan Notaris sah, karena bersumber dari UndangUndang No.2 Tahun 2014 yang merupakan kewenangan yang bersifat atributif, namun dalam pelaksanaan kewenangan tersebut memerlukan beberapa peraturan yang mendukung sebagai panduan serta arahan dalam pelaksanaan kebijakan agar tidak terjadi pertentangan kewenangan, sebagaimana perintah dari pasal 66A ayat (3) Undang-Undang No.2 Tahun 2014. Disamping legalitas kewenangan Majelis Kehormatan Notaris adalah sah secara hukum, kedudukannya dengan lembaga Majelis Pengawas Notaris sederajat namun, tugas, fungsi dan ruang lingkup kewenangan yang dimiliki masing masing lembaga tersebut berbeda.

\subsection{Saran}

1. Perlu segera adanya peraturan menteri yang mengatur khusus tentangtugas dan fungsi, syarat dan tata cara pengangkatan dan pemberhentian, struktur organisasi, tata kerja, dan anggaran Majelis Kehormatan Notaris, sehingga tidak ada tumpang tindih dengan lingkup kewenangan dengan lembaga notariat lain sebagaimana dengan majelis pengawas notaris 
2. Perlunya perubahan terhadap Keputusan Menteri Hukum dan Hak

Asasi Manusia RI Nomor : M39-

PW.07.10 Tahun 2004 dan

Peraturan Menteri Hukum Dan Hak

Asasi Manusia RI Nomor :

M.02.PR.08.10 Tahun 2004,

sehingga batas wewenang, tugas

dan fungsi dari majelis pengawas

tidak saling tumpang tindih dengan

Majelis Kehormatan Notaris.
Perlu ada peraturan pelaksana dari Undang-Undang No.2 tahun 2014 Tentang Perubahan Atas UndangUndang No.30 tahun 2004 Tentang jabatan Notaris sebagaimana perintah dari pasal 91B Undang-undang tersebut diatas.

\section{DAFTAR PUSTAKA}

\section{Buku}

Anke Dwi Saputro, Jati Diri Notaris Indonesia Dulu, Sekarang, dan di Masa Datang, Gramedia Pustaka, Jakarta , 2008.

Arya Utama, I Made, Hukum LingkunganSistem hukum Perizinan Berwawasan Lingkungan Untuk Pembangunan Berkelanjutan, Cet. 1, Pustaka Sutra, Bandung, 2007.

Indroharto, Usaha Memahami Undang-undang tentang Peradilan Tata Usaha Negara, Buku I. Pustaka Sinar Harapan, Jakarta, 1993.

Lumban Tobing, G.H.S, Peraturan Jabatan Notaris, Erlangga, Jakarta, 1999.

Marbun,SF., Peradilan Administrasi Negara dan Upaya Administrasi di Indonesia, UII Press, Yogyakarta, 2003.

, Menggali dan Menemukan Asas-asas Umum Pemerintahan Yang

Baik di Indonesia (Dimensi-Dimensi Pemikiran Hukum Administrasi Negara), UII Press, Yogyakarta, 2001.

Ridwan HR, Hukum Administrasi Negara, Rajawali Pers, Jakarta, 2010.

2006. Hukum Administrasi Negara, PT. Raja Grafindo Persada, Jakarta,

Saldi Isra, Pergeseran Fungsi Legislasi, Rajawali Pers, Jakarta, 2010.

Soerjono Soekantodan Sri Mamudji, Penelitian Hukum Normatif Suatu Tinjauan Singkat,edisi I Cetakan V, PT Raja Grafindo Persada Jakarta, 2001.

Sjachran Basah., Perlindungan Hukum Atas Sikap Tindak administrasi Negara, Alumni, Bandung, 1992.

\section{Kamus}

NE. Algra, H.R.W. Gokkel, Saleh Adiwinata, Boerhanoedin St. Batoeh, Kamus Istilah Hukum BelandaIndonesia, Fockema Andreal Belanda, Binacipta, Jakarta, 1983,

\section{Internet}

http://medianotaris.com/pasca_putusan_mk_kalau_benar_dan_taat_hukum_mengapa_resah_berita304.ht $\underline{\mathrm{ml}}$

http://www.hukumonline.com/berita/baca/lt51a4b3374d208/pemeriksaan-notaristak-perlu-persetujuan-mpd. 
Peraturan Perundang-undangan

Undang-Undang No. 30 tahun 2004 Tentang Jabatan Notaris (Lembaran Negara Republik Indonesia Tahun 2004 Nomor 117)

Undang-Undang No.2 Tahun 2014 Tentang Perubahan atas Undang-Undang No. 30 tahun 2004 Tentang Jabatan Notaris (Lembaran Negara Republik Indonesia Tahun 2014 Nomor 3)

Peraturan Menteri Hukum Dan Hak Asasi Manusia RI Nomor : M.02.PR.08.10

Tahun 2004 Tentang Tata Cara Pengangkatan Anggota, Susunan Organisasi, Tata Kerja, Dan Tata Cara Pemeriksaan Majelis Pengawas Notaris

Keputusan Menteri Hukum dan Hak Asasi Manusia RI Nomor : M39-PW.07.10

Tahun 2004 Tentang Pedoman Pelaksanaan Tugas Majelis Pengawas Notaris 